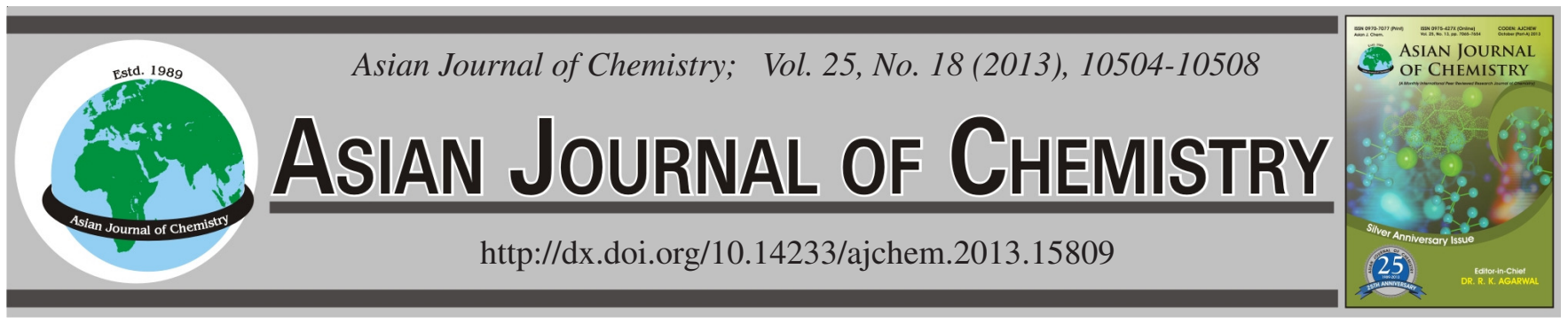

\title{
Chemical Composition of Spent Pleurotus eryngii Mushroom Substrate and Its Reuse for Volvariella volvacea Production
}

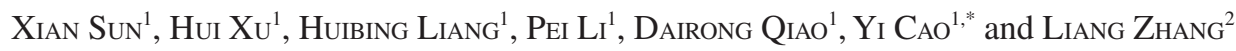

${ }^{1}$ Microbiology and Metabolic Engineering Key Laboratory of Sichuan Province, College of Life Science, Sichuan University, Chengdu 610065 , Sichuan Province, P.R. China

${ }^{2}$ College of Bioengineering, Xihua University, Chengdu 610039, P.R. China

*Corresponding author: Fax: +86 28 85411099; Tel: +86 28 85412842; E-mail: geneium@ scu.edu.cn

\begin{abstract}
The nutrient compositions, physical components and metal contents of spent Pleurotus eryngii mushroom substrate (SMS) and traditional wheat straw substrate (WS) were analyzed. The result show that SMS can be used for the cultivation of $V$. volvacea. The effects of compost of SMS, additive of WS, substrate moisture content and initials $\mathrm{pH}$ on yield, bioconversion efficiency, spawn growth and nutrition of fruit body were investigated. The cultivation result show that composted SMS was successfully used as basic substrate for V. volvacea production with adjusted the initial $\mathrm{pH}$ of 8 and $70 \%$ of moisture content. In laboratory and large scale cultivation experiments, the average biological efficiency of the cultivated on SMS were 26.12 and $27.42 \%$, respectively, considerably higher than the corresponding values on traditional WS controls of 17.92 and $20.17 \%$. The proximate composition, amino acids, trace elements of the fruit body cultivation between SMS and WS media were analyzed. The result indicated that $V$. volvacea cultivate on SMS had a higher nutritional value than those grown on WS.
\end{abstract}

Key Words: Spent mushroom substrate, Chemical composition, Mushroom cultivation, Nutrition analysis.

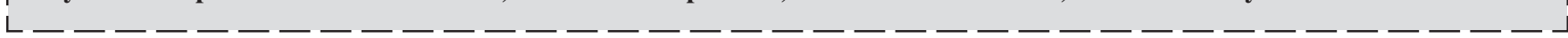

\section{INTRODUCTION}

Mushroom cultivation is currently the biggest solid-statefermentation industry in the world and a good bioconversion process for the utilization of a wide range of residues from the agro-industrial sector ${ }^{1}$. One of the major problems in the mushroom producing countries remains the treatment and disposal of the residues. After several mushroom cultivation cycles the productivity decreases and the residual by-product, known as spent mushroom substrate (SMS) has to be properly disposed of to avoid environmental problems, such as water and soil contamination, which result from the high level of organic and salt contents of the spent mushroom substrates.

It is generally acknowledged that SMS is a valuable material for improving soil structure in tilled soils owing to its highly organic nature ${ }^{2}$ and increasing dry matter production on grassland soils ${ }^{3}$. As a lignocellulosic material, SMS could potentially be a source of reducing sugars for production of biofuels and other biomaterials ${ }^{4-6}$. Furthermore, the use of SMSs on biodegradation of pollutants has also been well documented ${ }^{7-9}$. However, there are nearly few studies on the uses of fresh SMS from one mushroom production for cultivation of another mushroom.
Volvariella volvacea Singer, the Chinese straw mushroom, is a commercially important edible mushroom cultivated in tropical and subtropical regions and ranks fifth among cultivated mushrooms in terms of annual world-wide production $^{10}$. Unlike other cultivated edible mushrooms such as Agaricus bisporus, Lentinula edodes and Pleurotus sajorcaju, V. volvacea grows poorly on substrates with a high lignin content ${ }^{11}$ and its biological efficiency is very low ${ }^{12}$, because of its cellulolytic characteristics. Although some improvements have been achieved by replacing the traditional rice straw substrate with cotton waste, fruiting body yield is still lower than that of other popular cultivated mushrooms. One of the methods enhancing the productivity is to find a low-cost and high efficiency feedstock for mushroom cultivation.

The main objective of this work is to develop an economical bioprocess to produce $V$. volvacea. We also determined the effect of $V$. volvacea grown in different media of spent mushroom substrate in various ratios with straw, initial $\mathrm{pH}$; moisture content and superphosphate concentrate on cultivation parameters in pilot scale experiment. Moreover, we analyzed composition of $V$. volvacea production from spent mushroom substrate and traditional straw substrate. 


\section{EXPERIMENTAL}

The $P$. eryngii SMS used in the present study were obtained from a factory farming named Rong-zhen mushrooms Co., LTD. located in the city of Chengdu (Sichuan province), which is the largest industrialized mushroom cultivation company in southeast China. This SMS was composted and formulated with $50 \%$ sawdust, $25 \%$ cotton seed hulls and $25 \%$ wheat bran, supplemented with gypsum $\left(\mathrm{CaSO}_{4} \cdot 5 \mathrm{H}_{2} \mathrm{O}\right)$ and $\mathrm{CaCO}_{3}$ and supported 3-4 fruiting cycles. After drying SMS was ground to a particle size of $800 \mu \mathrm{m}$ and then stored in air-tight container at $4{ }^{\circ} \mathrm{C}$ for further use. $V$. volvacea strain V27, original strain, is preserved in Rong-zhen mushrooms Co., LTD. and was acquired for CGMCCC (China General Microbiological Culture Collection Center). The culture media used for routine culture and storage purposes were potato dextrose agar (PDA) and complete yeast medium (CYM). Grain spawn of species was prepared in $500 \mathrm{~mL}$ Erlenmeyer flasks filled with $180 \mathrm{~g}$ of boiled wheat (Triticum durum) grains supplemented with $3 \%$ calcium carbonate and $1.5 \%$ gypsum $(w / w$, in terms of dry weight). The contents of flasks were thoroughly mixed and autoclaved at $121{ }^{\circ} \mathrm{C}$ for $0.5 \mathrm{~h}$. Each flask was inoculated with mycelium scraped off the surface of a growing colony in a Petri dish (about $9 \mathrm{~cm}$ diam). Flasks were incubated at $26^{\circ} \mathrm{C}$ for 3 weeks, in the dark, with periodical shaking.

The lignin content of the raw spent mushroom substrate and acid hydrolysis residues were determined ${ }^{13-15}$ according to National Renewable Energy Laboratory Procedures LAP 001, 003 and 004. The carbohydrate composition of SMS was determined by High Performance Liquid Chromatography (Waters 2795, Waters corp., USA) with Evaporative Lightscattering Detector (All-Tech ELSD 2000, All-tech., corp., CA) using an Aminex HPX-87-Pb column (Bio-Rad, Hercules, USA) at $80{ }^{\circ} \mathrm{C}$ and flow rate of $0.6 \mathrm{~mL} / \mathrm{min}$ with distilled water as eluent. Nitrogen gas was used as carrier at the pressure of 3.2 Bar and draft temperature was $110{ }^{\circ} \mathrm{C}$ for the ELSD detector. Protein concentration was determined by the Kjeldahl method. Lipids concentration was determined by gravimetric analysis after solvent extraction with hexane (Soxhlet method). Ashes were quantified by gravimetric analysis after burning samples at $550{ }^{\circ} \mathrm{C}$ for $5 \mathrm{~h}$. Fibers concentration was calculated by difference. Moisture content was determined by gravimetric analysis after drying at $105^{\circ} \mathrm{C}$ to constant weight. The $\mathrm{C}, \mathrm{H}$, $\mathrm{N}$ was analyzed by $\mathrm{CHN}$ Analyzer with automatic sampler (Carlo-Erba elemental analyzer, Model 1106, Italy). The sample was digested in 5:1 nitric: perchloric acids and analyzed for $\mathrm{As}, \mathrm{Cr}, \mathrm{Cd}, \mathrm{Hg}, \mathrm{Pb}, \mathrm{Na}, \mathrm{K}, \mathrm{Ca}, \mathrm{Mg}, \mathrm{P}, \mathrm{Cu}, \mathrm{Mn}, \mathrm{Zn}$ and $\mathrm{Fe}$ using inductively coupled plasma atomic emission spectrometer (ICP-AES, Model IRIS 1000, Thermo Fisher, USA).

Substrate preparation: Non-composted substrate of SMS was prepared as follows: The $P$. eryngii SMS with particles size of $3 \mathrm{~cm}$ were soaked in water for $24 \mathrm{~h}$. After the surplus water had been drained off, substrates were mixed with $5 \%$ of limestone (dw) to obtain a $\mathrm{pH}$ value of 7 and were supplemented with wheat straw according to experimental design. The moisture content of the sterilized substrates was 60-75\% on the basis of requirement. Composted substrate of SMS was prepare as follows: About $300 \mathrm{~kg}$ of SMS from P. eryngii cultivation were filled in the drum, watered thoroughly, allowed to drain to obtain $65 \%$ moisture and subjected to a 15 day composting process. Mixing and aeration was achieved by periodic drum revolutions. Along with composting, temperature and moisture level were monitored daily just before turning and water was added as necessary to maintain $65-70 \%$ moisture content. Temperature raised at $65-70{ }^{\circ} \mathrm{C}$ in first 4 days, kept in the range of $50-65^{\circ} \mathrm{C}$ for the following 6 days and gradually dropped to $40{ }^{\circ} \mathrm{C}$ by the completion of the process.

Culture of $V$. volvacea by the $P$. eryngii SMS: Polypropylene-autoclavable bags were filled with $2.5 \mathrm{~kg}$ of substrate and were sterilized twice for $1 \mathrm{~h}$ at $121^{\circ} \mathrm{C}$. Inoculation was carried out along the central vertical axis of bag, at a rate of $3 \%(\mathrm{w} / \mathrm{w})$. Colonization of the substrates took place in growth chambers, in the darkness, at $37^{\circ} \mathrm{C}$. After complete colonization of the substrate, polypropylene bags were removed and environmental conditions (temperature, relative humidity, aeration and light intensity) were adjusted for basidiomata induction and maintained at the appropriate levels during the entire length of production cycles. During fructification, the light intensity was set at $700 \mathrm{lux}$ (12h/day, fluorescent lamps), air exchange rates were controlled to maintain low $\mathrm{CO}_{2}$ level $(<1200 \mathrm{ppm})$, relative air humidity was adjusted at $90 \%$ and temperature was set at $30{ }^{\circ} \mathrm{C}$. Three flushes of $\mathrm{V}$. volvacea mushrooms at the egg or elongation stage were harvested during the cropping period that lasted from 30-50 days, depending on the experiment. For fructification and productivity evaluation, three replicates per substrate were used. For all replicates, the time needed for complete substrate colonization and appearance of primordial was also recorded.

Calculations: Closed (lamellae not exposed) mushrooms were harvested, counted and weighed daily. At the end of each break, yield and bioconversion efficiency were determined as the ratio of fresh mushrooms $(\mathrm{g})$ harvested per dry substrate weight (g) and expressed as a percentage. Yield was expressed in $\mathrm{kg} / 100 \mathrm{~kg}$ substrates. Average mushroom productivity rate $(\mathrm{kg} / 100 \mathrm{~kg} /$ day) was calculated as the total yield of fresh mushrooms $(\mathrm{kg} / 100 \mathrm{~kg})$ over the total harvest period (day).

\section{RESULTS AND DISCUSSION}

Chemical composition of spent Pleurotus eryngii mushroom substrate: As shown in Table-1, initial $\mathrm{pH}$, average moisture content, $\mathrm{C} / \mathrm{N}$ rate, protein concentration, ashes, fibers and lipids of SMS dry matter (and rice straw substrate) were approximately 6.8 (6.7), $21.5 \%$ (18.1\%), 41.74 (36.84), $3.61 \%(1.42 \%), 6.02 \%(8.86 \%), 62 \%(37.45 \%)$ and $0.54 \%$ $(0.12 \%)(\mathrm{w} / \mathrm{w})$ respectively. The $\mathrm{C}, \mathrm{H}$ and $\mathrm{N}$ of SMS dry matter (and rice straw substrate) were approximately $59.59 \%$ (48.12\%), $7.93 \%(5.24 \%)$ and $1.64 \%(1.02 \%)$, respectively. The nutrient composition and physical component description between the SMS and traditional rice straw substrate for $V$. volvacea production were varied, where it is evident that SMS has a considerable supply of plant nutrients.

As shown in Table-2, As, Cr, Cd, Hg, Pb, Na, K, Ca, Mg, $\mathrm{P}, \mathrm{Cu}, \mathrm{Mn}, \mathrm{Zn}$ and $\mathrm{Fe}$ of SMS dry matter were approximately 0.16, 0.12, 0.83, 0.00006, 2.11, 244, 3927, 4671,1391, 1262, $2.9,13.1,5.6$ and $19.5(\mu \mathrm{g} / \mathrm{g})$, respectively. Though no legal heavy metal limits or standards have been published for SMS or indeed for any general compost produced in China, yet there 
TABLE-1

NUTRIENT COMPOSITIONS AND PHYSICAL COMPONENTS OF SMS AND RICE STRAW SUBSTRATE

\begin{tabular}{cccccccc}
\hline Substrate & $\mathrm{pH}$ & Moisture $(\%)$ & $\mathrm{C} / \mathrm{N}$ & Protein (\%) & Ashes (\%) & Fibers (\%) & Lipids (\%) \\
\hline SMS & $6.8 \pm 0.2$ & $21.5 \pm 0.6$ & $41.74 \pm 2.1$ & $3.61 \pm 0.11$ & $6.02 \pm 0.22$ & $62 \pm 3.04$ & $0.54 \pm 0.05$ \\
Rice straw & $6.7 \pm 0.2$ & $18.1 \pm 0.5$ & $36.84 \pm 1.55$ & $1.442 \pm 0.05$ & $8.86 \pm 0.13$ & $37.45 \pm 2.25$ & $0.12 \pm 0.02$ \\
\hline
\end{tabular}

TABLE-2

METAL CONTENTS OF SPENT Pleurotus eryngii MUSHROOM SUBSTRATE

\begin{tabular}{cc|cc}
\hline $\begin{array}{c}\text { Metal } \\
\text { element }\end{array}$ & $\begin{array}{c}\text { Concentration } \\
(\mu \mathrm{g} / \mathrm{g})\end{array}$ & $\begin{array}{c}\text { Metal } \\
\text { element }\end{array}$ & $\begin{array}{c}\text { Concentration } \\
(\mu \mathrm{g} / \mathrm{g})\end{array}$ \\
\hline $\mathrm{As}$ & $0.16 \pm 0.001$ & $\mathrm{Ca}$ & $4671 \pm 68.09$ \\
$\mathrm{Cr}$ & $0.12 \pm 0.001$ & $\mathrm{Mg}$ & $1391 \pm 20.87$ \\
$\mathrm{Cd}$ & $0.83 \pm 0.025$ & $\mathrm{P}$ & $1262 \pm 45.62$ \\
$\mathrm{Hg}$ & 0.00006 & $\mathrm{Cu}$ & $2.9 \pm 0.05$ \\
$\mathrm{~Pb}$ & $2.11 \pm 0.03$ & $\mathrm{Mn}$ & $13.1 \pm 0.25$ \\
$\mathrm{Na}$ & $244 \pm 10.25$ & $\mathrm{Zn}$ & $5.6 \pm 0.1$ \\
$\mathrm{~K}$ & $3927 \pm 109.22$ & $\mathrm{Fe}$ & $19.5 \pm 0.35$ \\
\hline
\end{tabular}

are standards implemented in many other European countries for general compost. These limits for lead range from 120 to $1200 \mathrm{mg} / \mathrm{kg}$, from 1 to $105 \mu \mathrm{g} / \mathrm{g}$ for cadmium, 70 to $750 \mu \mathrm{g} / \mathrm{g}$ for chromium, nickel from 20 to $400 \mu \mathrm{g} / \mathrm{g}$, copper from 90 to $1750 \mu \mathrm{g} / \mathrm{g}$ and zinc from 280 to $4000 \mu \mathrm{g} / \mathrm{g}^{16}$. According to our study, most of the heavy metals are passable and the values obtained are well within the recommended range in EU countries and should not be a cause for concern when applied to land, as elevated heavy metal concentrations negatively affect plant growth.

V. volvacea grown on composted and non-composted SMS: Many species of Pleurotus including P. eryngii for commercial are cultivated using a substrate consisting of various mixtures of wheat straw, hay, corncobs, seed hulls and meal, horse manure, chicken manure, inorganic fertilizer, calcium sulfate, peat moss and ground limestone $\mathrm{e}^{17-21}$. After mushroom harvest, the residual substrate is pasteurized and either discarded or sold as spent mushroom compost. In order to assess the potential of SMS as a feedstock for $V$. volvacea production, the mycelium growth, total mushroom yield and bioconversion efficiency were determined on composted and non-composted SMS. As shown in Table-3, the composted substrates supported better substrate colonization for $V$. volvacea than non-composted substrate, e.g. on composted SMS the mycelium growth, total yield weight and bioconversion efficiency were reduced by $63.12,41.65$ and $37.08 \%$ respectively. In previous reports, there were contradiction results about the growth of $V$. volvacea on composted and noncomposted SMS, expecially for different strain of $V$. volvacea ${ }^{22,23}$. In this study, it is concluded that composted SMS from

\begin{tabular}{cccc}
\multicolumn{4}{c}{ TABLE-3 } \\
EFFECT OF V. volvacea GROWN ON \\
COMPOSTED AND NON-COMPOSTED \\
\hline \multirow{3}{*}{ Substrate } & $\begin{array}{c}\text { Mycelium } \\
\text { growth rates } \\
(\mathrm{mm} / \mathrm{d})\end{array}$ & $\begin{array}{c}\text { Bioconversion } \\
\text { efficiency }(\%)\end{array}$ & $\begin{array}{c}\text { Total yield } \\
\text { weight }(\mathrm{Kg})\end{array}$ \\
\hline Composted SMS & $12.7 \pm 0.25$ & $17.17 \pm 0.68$ & $18.48 \pm 0.73$ \\
Non-composted & $4.6 \pm 0.14$ & $10.16 \pm 0.45$ & $11.64 \pm 0.51$ \\
\hline
\end{tabular}

$P$. eryngii cultivation achieved better growth of $V$. volvacea than non-composted one.

V. volvacea grown on different media of composted SMS in various ratios with wheat straw: In order to compare composted SMS and traditional wheat straw as substrate for $V$. volvacea production, the fruit body yield, bioconversion efficiency, harvest cycle and spawn grown have been analyzed. As shown in Table-4, the SMS was blended with wheat straw (WS) at $0,5,10,15,25$ and $95 \%$ on a wet basis and including $5 \%$ limestone. Six treatments included SMS $95 \%$, SMS 90 $\%+$ WS $5 \%$, SMS $85 \%+$ WS $10 \%$, SMS $80 \%+$ WS $15 \%$, SMS $70 \%+$ WS $25 \%$ and WS $95 \%$. According to our study, bioconversion efficiency of $V$. volvacea from adding some SMS was higher than those under traditional wheat straw substrate condition. Perhaps because SMS have amount of fermentable nutrient which comes from the hydrolase activity of $P$. eryngii that could been easily utilized. Philippoussis et al..$^{23}$ reported that $V$. volvacea grow better on cotton waste than WS and peanut shells. In addition positive correlation was also detected between cellulose content and mushroom yield for $V$. volvacea strain. In the case of our research, high content of fiber was detected in SMS (62\% of fiber in total dry matter) rather than WS (37.45\% of fiber in total dry matter), which may the reason for better bioconversion efficiency on SMS.

Furthermore, the mushrooms produced from 1st flush commonly have best appearance and qualities. Adding amount of SMS could remarkable increased the yield of 1st flush, the mushroom yield with SMS was about $50 \%$ higher than with wheat straw. In all substrate with adding SMS, an average mushroom productivity rate yield was $16.44 \mathrm{~g} / \mathrm{d}$, considerably higher than the corresponding values for WS controls of 12.8 $\mathrm{g} / \mathrm{d}$. Fasola et al. ${ }^{24}$ evaluated the mycelial growth of Volvariella speciosa (Fr. Ex. Fr.) Singer on synthetic and semi-synthetic

TABLE-4

SUBSTRATE CONDITION AND RESULT OF $V$. volvacea CULTIVATION ON WHEAT STRAW AND SMS

\begin{tabular}{|c|c|c|c|c|c|c|c|c|}
\hline \multirow{2}{*}{ Substrate (w/w) } & \multirow{2}{*}{$\begin{array}{l}\text { Spawn } \\
\text { grown }\end{array}$} & \multicolumn{3}{|c|}{ Mushroom yield distribution (\%) } & \multirow{2}{*}{$\begin{array}{c}\text { Total yield } \\
\text { (g) }\end{array}$} & \multirow{2}{*}{$\begin{array}{l}\text { Total harvest } \\
\text { period (day) }\end{array}$} & \multirow{2}{*}{$\begin{array}{l}\text { Bioconversion } \\
\text { efficiency }(\%)\end{array}$} & \multirow{2}{*}{$\begin{array}{l}\text { Productivity } \\
\text { (g/d) }\end{array}$} \\
\hline & & 1st Flush & 2nd Flush & 3rd Flush & & & & \\
\hline SMS $95 \%$ & + & $56.10 \pm 2.56$ & $30.2 \pm 1.98$ & $13.66 \pm 1.86$ & $653.0 \pm 18.73$ & 36 & $26.12 \pm 0.75$ & $18.14 \pm 0.52$ \\
\hline SMS $90 \%$ + WS $5 \%$ & ++ & $53.80 \pm 0.91$ & $30.3 \pm 0.96$ & $15.8 \pm 2.15$ & $610.0 \pm 23.45$ & 35 & $24.40 \pm 0.94$ & $17.40 \pm 0.67$ \\
\hline SMS $85 \%+$ WS $10 \%$ & +++ & $52.20 \pm 2.39$ & $30.4 \pm 0.72$ & $17.4 \pm 1.77$ & $537.5 \pm 11.69$ & 33 & $21.50 \pm 0.46$ & $16.30 \pm 0.35$ \\
\hline SMS $80 \%+$ WS $15 \%$ & +++ & $50.30 \pm 3.31$ & $29.8 \pm 0.92$ & $19.9 \pm 0.50$ & $490.0 \pm 19.33$ & 31 & $19.60 \pm 0.77$ & $15.80 \pm 0.62$ \\
\hline SMS $70 \%+$ WS $25 \%$ & ++++ & $52.00 \pm 2.43$ & $30.9 \pm 3.38$ & $17.1 \pm 1.22$ & $465.8 \pm 20.57$ & 32 & $18.63 \pm 0.82$ & $14.60 \pm 0.64$ \\
\hline WS $95 \%$ & ++++ & $49.07 \pm 4.97$ & $33.3 \pm 2.33$ & $17.6 \pm 0.54$ & $448.0 \pm 15.52$ & 35 & $17.92 \pm 0.62$ & $12.80 \pm 0.44$ \\
\hline
\end{tabular}

*All the substrate were added $5 \%(w / w)$ limestone 
media, as well as different agro-industrial wastes and found among the different agricultural substrates used, growth was poor on fresh cow dung and poultry droppings and enhanced mostly on maize and andropogon gianus straw but greatest mycelial density was obtained with cassava peels. Likewise, the growth of mycelial was poor with the substrate adding SMS. This low growth may be due to high containing of ammonia, comes from residual of $P$. eryngii cultivation which may inability of $V$. volvacea to secrete hydrolyzing enzyme, which would convert the substrate to utilizable amino acids and carbon compounds necessary for growth, are toxic to mycelial growth of fungi ${ }^{25}$.

Effect of $\mathrm{pH}$ and moisture content on $\mathrm{V}$. volvacea cultivation by spent mushroom substrate: The mushroom yield, including 1st flush, 2nd flush and 3rd flush for different test conditions are given in Figs. 1 and 2. The test runs 1-5 and 6-10 were carried out as three separate cultivation runs to determine the effect of $\mathrm{pH}$ and moisture content on the mushroom growth on SMS $95 \%$ and limestone $5 \%$. According to the results presented in Figs. 1 and 2, the difference of $\mathrm{pH}$ and moisture content caused a difference in total bioconversion efficiency.

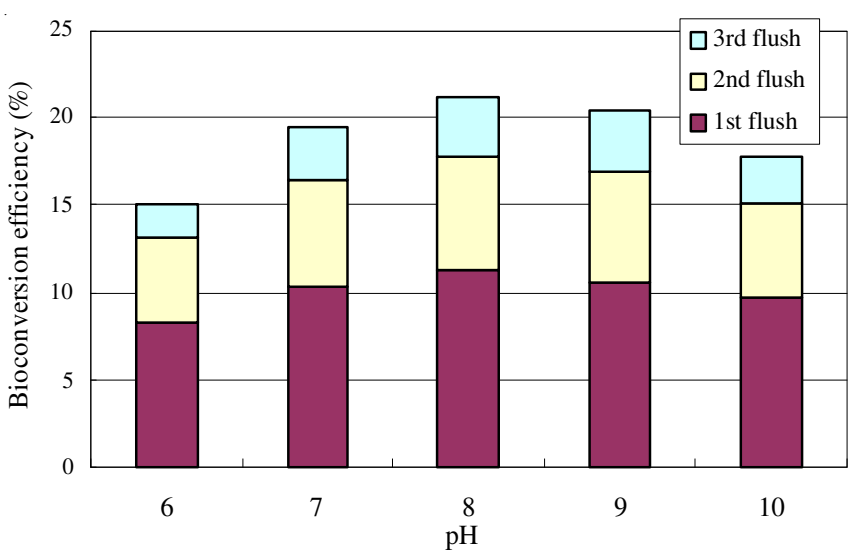

Fig. 1. Effect of $\mathrm{pH}$ on $V$. volvacea cultivation by SMS

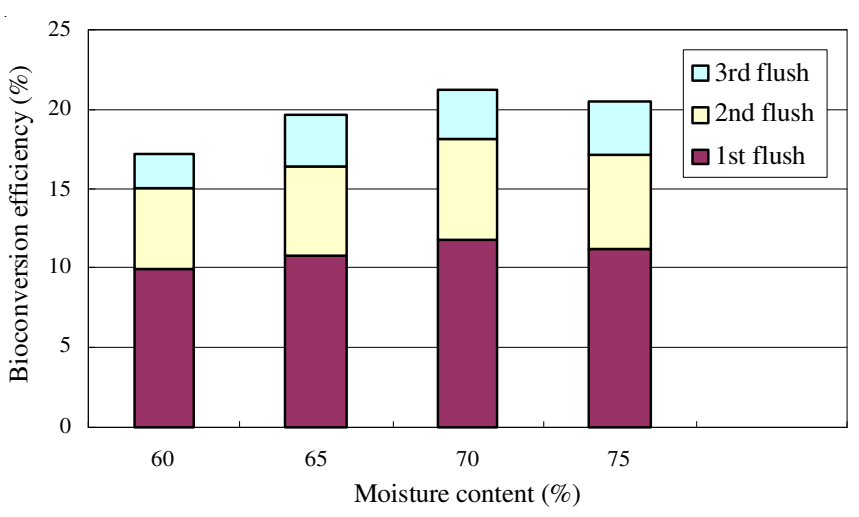

Fig. 2. Effect of moisture content on $V$. volvacea cultivation by SMS

As shown in Fig. 1, the mycelial growth of $V$. volvacea was obtained in the $\mathrm{pH}$ range 6 to 10. It was observed that the best bioconversion efficiency $(22.6 \%)$ was observed in the slightly alkaline $\mathrm{pH}$ of 8 while good growths $(18.9 \%$ and $20.1 \%$ ) were also obtained at $\mathrm{pH} 7$ and 9. This result implies that $V$. volvacea prefers alkaline $\mathrm{pH}$ values, tending toward neutrality. This result is similar to those obtained by Fasidi ${ }^{26}$ (for V. esculenta) and Jonathan ${ }^{27}$ (for L. procera). Generally, vegetative growth of this mushroom was reduced at high acidic and alkaline $\mathrm{pH}$. Hopkins ${ }^{28}$ reported that, at high acidic or alkaline $\mathrm{pH}$, cell wall and tonoplast of plants may corrode and selective permeability function of the cell membrane may be impaired. This may be the reason why there were no good growths at $\mathrm{pH} 6$ and 10 .

It has been known that the substrate moisture content is the important factor affecting mycelia growth and fruit body yield, in addition to chemical components of substrate ${ }^{29,30}$. Fig. 2 shows the variation of bioconversion efficiency in relation to moisture content by SMS. The bioconversion efficiency value increased with the moisture content and peaked at about $70 \%$. These results suggest the optimum moisture content of V. volvacea cultivation by SMS is around $70 \%$ and this result is similar to the earlier observation of Alofe ${ }^{31}$ who reported that L. subnudus and P. tuber-regium grew on agricultural wastes at different moisture contents.

Nutrition analysis of $\boldsymbol{V}$. volvacea produced from SMS and traditional substrate: To evaluate the nutritional value of $V$. volvacea, the proximate composition, amino acids, trace elements of the fruit body cultivation between SMS and WS media were analyzed. As shown in Table-5, the cultivation on SMS had a greater potential to improve the accumulation of TKN, K, Ca, P and $\mathrm{Na}$ than did on WS substrate. This difference is in agreement with the analyses of $V$. volvacea cultivated on different substrate, composed of orange juice waste, bagasse, rice straw, horse manure, molasses and urea. In addition, the type of substrate also affected the amino acid profile, even though protein contents were similar in SMS and WS substrate. As shown in Table-6, the fruit bodies harvested from SMS contained all the essential amino acids, which comprised $39.8 \%$ of total Kjeldahl protein. This result may attribute to not only the initial amount but also the nature of nitrogen source present in substrate influences the protein content of fruit bodies, which is in accordance with the literatures $^{32,33}$. Furthermore, as regard shelf life, harvested sporophores grown on SMS showed a higher degree of color change from brown to black than those grown on traditional WS media (pictures not showed). This phenomenon was significantly reduced by packaging sporophores under a polyethylene film and need to be further research.

\section{Conclusion}

According to the results, it could be concluded that SMS from $P$. eryngii production is an attractive feedstock for the $V$. volvacea cultivation, especially in China which is the world's largest mushroom producer. Since composited SMS could provided the necessary nutrient element and the appropriate heavy metal concentrations for the fermentation of other mushroom such as $V$. volvacea, there was no need for supplementing these additionally. Moreover, the total mushroom yield, bioconversion efficiency, productivity, nutrition analysis and amino composition of fruit body cultivated on SMS were comparable to traditional wheat straw based substrate cultivation from both the economic standpoints and environmentally friendly. 
TABLE-5

CHEMICAL COMPOSITION OF THE FRUIT BODY OF $V$. volvacea PRODUCED FROM SMS AND TRADITIONAL SUBSTRATE

\begin{tabular}{ccccccccc}
\hline \multirow{2}{*}{ Substrate } & \multicolumn{7}{c}{ Nutrient composition (\%) } \\
\cline { 2 - 9 } & TKG & Lipid & TRS & Ash & K & Ca & P & Na \\
\hline SMS & $30.23 \pm 1.08$ & $1.13 \pm 0.05$ & $0.49 \pm 0.02$ & $9.01 \pm 0.18$ & $6.083 \pm 0.15$ & $0.360 \pm 0.002$ & $1.185 \pm 0.02$ & $0.169 \pm 0.003$ \\
WS & $28.02 \pm 0.59$ & $1.25 \pm 0.03$ & $0.53 \pm 0.01$ & $9.00 \pm 0.41$ & $5.862 \pm 0.23$ & $0.325 \pm 0.001$ & $1.087 \pm 0.02$ & $0.156 \pm 0.001$ \\
\hline
\end{tabular}

TABLE-6

AMINO ACID COMPOSITION OF THE FRUIT BODY OF $V$. volvacea PRODUCED FROM SMS AND TRADITIONAL SUBSTRATE

\begin{tabular}{|c|c|c|c|c|c|c|c|c|c|}
\hline \multirow{2}{*}{ Substrate } & \multicolumn{9}{|c|}{ Amino acid composition (\%) } \\
\hline & Leucine & Isoleucine & Lysine & Methionine & Phenylalanine & Threonine & Valine & Tryptophan & Total \\
\hline Ideal protein & 7 & 4 & 5.5 & 3.5 & 6 & 4 & 5 & 1 & 36 \\
\hline SMS & $7.1 \pm 0.22$ & $3.8 \pm 0.05$ & $9.6 \pm 0.34$ & $1.3 \pm 0.02$ & $4.4 \pm 0.1$ & $4.3 \pm 0.13$ & $7 \pm 0.17$ & $2.3 \pm 0.04$ & $39.8 \pm 1.07$ \\
\hline WS & $6.9 \pm 0.08$ & $4.3 \pm 0.13$ & $9.8 \pm 0.26$ & $1.2 \pm 0.04$ & $2.6 \pm 0.12$ & $3.4 \pm 0.12$ & $6.5 \pm 0.09$ & $1.2 \pm 0.05$ & $35.9 \pm 0.89$ \\
\hline
\end{tabular}

\section{ACKNOWLEDGEMENTS}

This study was supported by the Ministry of Education of China (Spring Plan), Department of education of Sichuan Province, NSFC (J1103518), Sichuan Science and Technology Bureau(2012GZ0008, 2013GZ0058), and Key R \& D Program Fund of Xihua University (Z1120538).

\section{REFERENCES}

1. C.R. Soccol and L.P.S. Vandenberghe, Eng. J., 13, 205 (2008).

2. J.A. Buswell, Y.J. Cai, S.T. Chang, J.F. Peberdy, S.Y. Fu and H.S. Yu, World J. Microbiol. Biot., 12, 537 (1996).

3. S.T. Chang, Mushroom J., 21, 348 (1974).

4. J. Wang, L. Guo, K. Zhang, Q. Wu and J. Lin, Bioresour. Technol., 99, 8524 (2008).

5. M.J. Maher, S. Smyth, V.A. Dodd, T. McCabe, W.L. Magette, J. Duggan and M.J. Hennerty, Managing Spent Mushroom Compost, Teagasc, Dublin (2000).

6. G.J. Mullen and C.A. McMahon, Irish J. Agric. Food Res., 40, 189 (2001).

7. L.C.C. Ribas, M.M. Mendonça, C.M. Camelini and C.H.L. Soares, Bioresour. Technol., 100, 4750 (2009).

8. E. Medina, C. Paredes, M.D. Pérez-Murcia, M.A. Bustamantea and R. Morala, Bioresour. Technol., 100, 4227 (2009).

9. S.W. Chiu, T. Gao, C.S.S. Chan and C.K.M. Ho, Chemosphere, 75, 837 (2009).

10. S. McCahey, J.T. McMullan and B.C. Williams, Dev. Chem. Eng. Miner. Proc., 11, 43 (2003).

11. K.N. Finney, C. Ryu, V.N. Sharifi and J. Swithenbank, Bioresour. Technol., 100, 310(2009).

12. V. Balan, L. da Costa Sousa, S.P.S. Chundawat, R. Vismeh, A.D. Jones and B.E. Dale, J. Ind. Microbiol. Biotechnol., 35, 293 (2008).

13. T. Ehrman, LAP-001: Standard Method for Determination of Total Solids in Biomass, NREL (1994).
14. T. Ehrman, Laboratory Analytical Procedure LAP 004: Determination of Acid-Soluble Lignin in Biomass, NREL (1996).

15. D. Templeton and T. Ehrman, Laboratory Analytical Procedure LAP-003: Determination of Acid-Insoluble Lignin in Biomass, NREL (1995).

16. W.F. Briton, Biocycle, 42, 4 (2001).

17. G.V. Thomas, S.R. Prabhu, M.Z. Reeny and B.M. Bopaiah, World J. Microbiol. Biotechnol., 14, 879 (1998).

18. A. Philippoussis, P. Diamantopoulou and C. Israilides, Int. Biodeter. Biodegrad., 59, 216 (2007).

19. M. Obodai, J. Cleland-Okine and K.A. Vowotor, J. Indian Microbiol. Biotechnol., 30, 146 (2003).

20. O.O. Osemwegie, O.S. Isikhuemhen, O.J. Onyolu and J.A. Okhuoya, Int. J. Med. Mushrooms, 4, 343 (2002).

21. R. Zhang, X. Li and J.G. Fadel, Bioresour. Technol., 82, 277 (2002).

22. S.M. Khan, R. Haq and M.A. Dogar, in: Proceeding of the 13th International Congress on the Science and Cultivation of Edible Fungi, pp. 579-584 (1991).

23. A. Philippoussis, G. Zervakis and P. Diamantopoulou, World J. Microbiol. Biotechnol., 17, 191 (2001).

24. T.R. Fasola, J.S. Gbolagade and I.O. Fasidi, Food Chem., 100, 904 (2007).

25. F.Y. Zhao, J.F. Lin, X.L. Zeng, L.Q. Guo, Y.H. Wang and L.R. You, Bioresour. Technol., 101, 6482 (2010).

26. I.O. Fasidi, Food Chem., 55, 161 (1996).

27. S.G. Jonathan, Ph.D. Thesis, University of Ibadan, Ibadan, Nigeria (2002).

28. W.G. Hopkins, Introduction to Plant Physiology, John Wiley \& Sons Inc., USA (1995).

29. F. Zadrazil and H. Brunnert, Eur. J. Appl. Microbiol. Biotechnol., 11, 183 (1981)

30. S. Kumaran, C.A. Sasatry and S. Vikineswary, Malaysia Appl. Biol., 25, 119 (1996).

31. F.V. Alofe, Ph.D Thesis, Obafemi Awolowo University, Ile-Ife, Nigeria (1985).

32. S. Rapior, D. Moussain, C. Plassard, C. Andary and L. Salsac, Trans. British Mycol. Soc., 90, 181 (1988).

33. K. Tshinyangu, Nahrung, 40, 79 (1996). 